\title{
Family recognition of celiac disease
}

\author{
Dorota Szałowska' ${ }^{1}$ Leokadia Bąk-Romaniszyn ${ }^{2,3}$ \\ ${ }^{1}$ Department of Pediatrics, Preventive Cardiology and Clinical Immunology, Medical University of Lodz, Poland \\ 2Department of Pediatrics, Immunology and Nephrology, Polish Mothers Memorial Hospital Research Institute, Lodz, Poland \\ ${ }^{3}$ Department of Nutrition in Gastrointestinal Diseases, Medical University of Lodz, Poland
}

Key words: gluten, celiac disease, children, antibodies, genotype.

\begin{abstract}
Address for correspondence: Dorota Szałowska MD, PhD, Department of Pediatrics, Preventive Cardiology and Clinical Immunology, Polish Mothers Memorial Hospital Research Institute, 281/289 Rzgowska St, 93-338 Lodz, Poland, phone: +48 606282806 , e-mail: d.szalowska@interia.pl
\end{abstract}

\begin{abstract}
Celiac disease is a permanent intolerance to gluten that leads to small-bowel mucosal villous atrophy during autoimmune processes in genetically predisposed individuals. At present the diagnosis of celiac disease is based on characteristic clinical symptoms, the results of serological investigations (tissue transglutaminase ten times the upper limit of normal, presence of antiendomysial antibodies - EMA) and positive results of genetic examinations. The aim of this study is to present a medical history of a family in which the mother and younger son were diagnosed with celiac disease (confirmed by genotype examination). Before the genetic examination, the father and the elder son were also suspected of suffering from this disease (they were on gluten-free diets). The authors emphasize the usefulness of HLA-DQ2/DQ8 determination in first-degree relatives of celiac patients.
\end{abstract}

\section{Introduction}

Celiac disease (CD) is a permanent intolerance to gluten, which in genetically susceptible individuals leads to autoimmune enteropathy involving the small bowel [1]. Gluten is a polypeptide, found in wheat (gliadin), rye (decalin) and barley (hordein), which is resistant to gastric juice and proteolytic enzyme activity. After its consumption in genetically predisposed individuals it activates the immune system, which leads to enteropathy with small-bowel mucosal villous atrophy. The presence of anti-gliadin antibodies and tissue transglutaminase in blood is a serological exponent of the organism humoral response.

The first symptoms of celiac disease appear in infants about 4-6 weeks after introduction of flour products containing gluten into the diet. Typical symptoms include chronic diarrhoea or abundant, oily smelly stools (steatorrhoea), abdominal pain, bloating and distension, and failure to thrive. Over time, failure to thrive, psychomotor retardation, behavioural disorders ('a sad child') and recurring oral cavity aphthae increase. Dermatitis herpetiformis may develop (Duhring's disease).

The symptoms of the disease mainly depend on the patient's age, and thus in small children they include failure to thrive, lack of appetite, anaemia, abdominal bloating, pain and distention, muscle weakness, hyperaminotransaminasaemia and abundant stools. Celiac symptoms in schoolchildren and adolescents include failure to thrive, delayed puberty, persistent aphthae in the oral cavity, learning disabilities, abnormal bowel movements (constipation or diarrhoea), lactose intolerance, anaemia resistant to treatment, retarded sexual maturation and enamel hypoplasia. In adults the symptoms of celiac disease can occur after 40 year of age and they include persistent aphthae, body mass in$\operatorname{dex}(\mathrm{BMI})<18 \mathrm{~kg} / \mathrm{m}^{2}$, depression or mood depression, absence of menstrual periods, miscarriage in women, infertility in men, osteopenia or osteoporosis, anaemia resistant to treatment, diarrhoea or constipation and other autoimmune diseases (hyperthyroidism, autoimmune hepatitis, connective tissue diseases) [2].

In adolescents and adults celiac disease often presents an atypical monosymptomatic form in which one symptom dominates, e.g. constipation, early osteopenia or osteoporosis, anaemia, neurological or psychiatric symptoms or fertility disorders [3, 4] (Table I).

A gluten-free diet, followed restrictively, is the base of celiac disease treatment. 
Table I. Characteristics of children and adolescents with celiac disease (CD) [4]

\begin{tabular}{|c|c|c|c|}
\hline Feature & $\begin{array}{l}\text { Percentage of total no. children/ } \\
\text { adolescents with CD }\end{array}$ & Study population & Studies \\
\hline Iron-deficiency anaemia & $\begin{array}{c}3-12 \\
16\end{array}$ & $\begin{array}{l}\text { Adults and children } \\
\text { Adults and children }\end{array}$ & $\begin{array}{l}\text { Bottaro } 1999 \\
\text { Emami } 2008\end{array}$ \\
\hline $\begin{array}{l}\text { Another or unspecified } \\
\text { anaemia }\end{array}$ & $\begin{array}{c}3-19 \\
23\end{array}$ & $\begin{array}{l}\text { Adults and children } \\
\text { Adults and children }\end{array}$ & $\begin{array}{l}\text { Dickey } 1997 \\
\text { Vilppula } 2008\end{array}$ \\
\hline Anorexia & $\begin{array}{c}8 \\
26-35\end{array}$ & $\begin{array}{l}\text { Adults and children } \\
\text { Children }\end{array}$ & $\begin{array}{l}\text { Bottaro } 1993 \\
\text { Bottaro } 1999\end{array}$ \\
\hline Weight loss & $\begin{array}{c}44-60 \\
6\end{array}$ & $\begin{array}{l}\text { Children and adults } \\
\text { Children and adults }\end{array}$ & $\begin{array}{l}\text { Bottaro } 1993 \\
\text { Dickey } 1997\end{array}$ \\
\hline $\begin{array}{l}\text { Abdominal distension/ } \\
\text { bloating }\end{array}$ & $\begin{array}{c}28-36 \\
10 \\
20-39\end{array}$ & $\begin{array}{l}\text { Children } \\
\text { Adults and children } \\
\text { Children }\end{array}$ & $\begin{array}{c}\text { Bottaro } 1993 \\
\text { Garampazzi } 1997 \\
\text { Enama } 2008\end{array}$ \\
\hline Abdominal pain & $\begin{array}{c}12 \\
8 \\
11-21 \\
90 \\
\end{array}$ & $\begin{array}{l}\text { Adults and children } \\
\text { Adults and children } \\
\text { Children } \\
\text { hildren }\end{array}$ & $\begin{array}{c}\text { Garampazzi } 2007 \\
\text { Rashid } 2005 \\
\text { Emami } 2008 \\
\text { Dickey } 1997 \\
\end{array}$ \\
\hline Vomiting & $26-33$ & Children & Bottaro 1993 \\
\hline Flatulence & 5 & Adults and children & Emami 2008 \\
\hline Diarrhoea & $\begin{array}{c}70-75 \\
51 \\
13 \\
12-60\end{array}$ & $\begin{array}{l}\text { Children } \\
\text { Adults and children } \\
\text { Adults and children } \\
\text { Children }\end{array}$ & $\begin{array}{c}\text { Bottaro } 1993 \\
\text { Garampazzi } 2007 \\
\text { Emami } 2008 \\
\text { Dickey } 1997\end{array}$ \\
\hline $\begin{array}{l}\text { Short stature/growth } \\
\text { failure }\end{array}$ & $\begin{array}{c}19 \\
20-31\end{array}$ & $\begin{array}{l}\text { Adults and children } \\
\text { Children }\end{array}$ & $\begin{array}{l}\text { Bottaro } 1999 \\
\text { Dickey } 1997\end{array}$ \\
\hline Irritability & $10-14$ & Children & Bottaro 1993 \\
\hline $\begin{array}{l}\text { Increased level of liver } \\
\text { enzymes }\end{array}$ & 5 & Adults and children & Dickey 1997 \\
\hline Chronic fatigue & 7 & Adults and children & Dickey 1997 \\
\hline Failure to thrive & $48-89$ & Children & Garampazzi 2007 \\
\hline Constipation & $4-12$ & Children & Garampazzi 2007 \\
\hline Irregular bowel habits & $4-12$ & Children & Garampazzi 2007 \\
\hline
\end{tabular}

The aim of the study is to present a family of 5 in which celiac disease was diagnosed in the mother and younger son (confirmed by HLA-DQ2/DQ8 genotype examination). Before the genetic examination the father and the two sons (remaining on gluten-free diets) were suspected of suffering from this disease. The mother was treated as a healthy subject in the family.

\section{Case reports}

\section{Children}

Child 1: a 12.5-year-old boy, with CIPI, born on time, body weight $3650 \mathrm{~g}$, Apgar score 10, breastfed for the first 14 months of life, gluten introduced in the $10^{\text {th }}$ month of life (in compliance with then binding infant feeding recommendations). In the first year of life normal weight and height gain was observed, stools 5-6/ day, after juices (except for apple juice) undigested. Recurrent respiratory infections from the second year of age 5 times, accompanied by reactive arthritis up to the fifth year of age. In the second and third year of life the child complained of abdominal pain, loose stools and he ate meals reluctantly and in small quantities. Soya preparation was introduced into the diet and periodically oral antihistaminic drugs. At 3 years of age, skin-prick tests were performed - negative (grass, corn, trees, weeds, mould, fur, feather, meat, tropical fruit, cow milk, egg, cocoa) and specific IgE-class 0 (hazelnut, peanut, walnut, almond, milk, egg white, egg yolk, 
casein, potato, celery, carrot, tomato, codfish, shrimp, peach, apple, soya, wheat flour, sesame, rye flour). At 5 years of age, the child's body weight was $17 \mathrm{~kg}$ (10$25 \mathrm{c})$, height $110 \mathrm{~cm}(50 \mathrm{c})$ and BMI $14.0 \mathrm{~kg} / \mathrm{m}^{2}$ (25 c). Serological tests related to celiac disease and allergy were performed: IgA anti-tissue transglutaminase antibodies (tTGA IgA) - $0.2 \mathrm{U} / \mathrm{ml}(\mathrm{N}:<8 \mathrm{U} / \mathrm{ml})$, AGA IgA 2.0 $\mathrm{U} / \mathrm{ml}(\mathrm{N}:<11 \mathrm{U} / \mathrm{ml}), \mathrm{AGA} \operatorname{lgG}-3.9 \mathrm{U} / \mathrm{ml}(\mathrm{N}:<11 \mathrm{U} / \mathrm{ml})$ and specific lgE: gluten/gliadin positive in class $2, \beta$-lactoglobulin in class 2. Despite negative serological markers for celiac disease, a gluten-free and lactose-free diet was introduced due to IgE specific for gluten in class 2 . The change of diet resulted in regression of abdominal pain, improvement of appetite and significant decrease in the occurrence of respiratory infections. Abdominal pain and loose stools were observed when the diet was not obeyed. At 8 years of age he was diagnosed due to severe abdominal pain, loose stools and detection of significant Saccharomyces fungal infection (tTGA, AGA, IgA and IgG - normal). At 11 years of age the boy underwent therapy due to ascariasis and intestinal dysbacteriosis (diagnosed on the basis of positive hydrogen breath test with lactulose). Each introduction of gluten into the diet changed the child's behaviour and caused memory problems, worse learning results, abdominal pain and alternating stools.

At 12 years of age, his body weight was $44 \mathrm{~kg}$ (50-75 c), height $146 \mathrm{~cm}(10-25 \mathrm{c})$ and BMI $20.6 \mathrm{~kg} / \mathrm{m}^{2}$ (75 c). The boy was subjected to genotype examination to identify predispositions to celiac diseases. A negative HLA-DQ2/DQ8 test result was obtained which allowed final exclusion of celiac disease in the child and a diagnosis of food allergy to gluten and milk. Gradual introduction of gluten into the diet was recommended.

Child 2: a boy, 10 years old, with CIIPII, born on time, spontaneous labour, body weight 4150 g, Apgar 10 scores, breastfed to 2.5 years of age; other products were introduced according to the guidelines, including gluten in the eighth month of life. A few weeks after the introduction of gluten into the diet, he started to have loose stools, abdominal pain and unpleasant breath. After introduction of cow milk into the diet atopic skin changes appeared all over the body and he again had loose stools (3-5/day). First, casein hydrolyzate (no improvement) and then soy mixture were included into the diet. Within the first years of the boy's life he suffered recurrent respiratory infections, during the course of which reactive arthritis was detected twice. The boy had permanent ophthalmological supervision due to left eye amblyopia (congenital optic nerve defect, complicated cataract of the left eye). At 3 years of age the child's body weight was $14.5 \mathrm{~kg}(25-50 \mathrm{c})$, height $100 \mathrm{~cm}$ (75 c) and BMI $14.5 \mathrm{~kg} / \mathrm{m}^{2}$ (15-25 c). Additionally performed examination results were as follows: specific IgE: -lactoglobulin and gluten were positive in class 2 and IgE specific to dog epidermis and D. farinae in class 1. Furthermore, tTGA IgA $69.7 \mathrm{U} / \mathrm{ml}(\mathrm{N}:<8.0 \mathrm{U} / \mathrm{ml})$, AGA antibodies - IgA $1.4 \mathrm{U} / \mathrm{ml}(\mathrm{N}:<11.0 \mathrm{U} / \mathrm{ml})$ and AGA - IgG $5.0 \mathrm{U} / \mathrm{ml}(\mathrm{N}:<11.0 \mathrm{U} / \mathrm{ml})$. Tests from fresh natural food were performed by 'skin trick-prick test' (SSPT) for gluten-free flour mix and gluten-free pasta: negative - erythema and wheal absent (0) but for gluten-free pastry DBPCFC patch test++++.

The parents failed to give consent for a small-intestinal biopsy. On the basis of clinical symptoms and serological tests, food allergy and celiac disease were diagnosed in the boy. A gluten- and milk-free diet was introduced, obtaining after 6 months normalization of tTGA concentration, regression of abdominal pain and normalization of stool consistency.

In later years, after every dietetic error associated with the administration of gluten, recurrent abdominal pain and depression of mood were observed in the child. The results of celiac disease control indicators (tTGA, EMA antibodies) were checked at 9 and 10 years of age in the range of reference standards. At the age of 10 years his body weight was $29 \mathrm{~kg}$ (25 c), height $141 \mathrm{~cm}(75-90 \mathrm{c}), \mathrm{BMI} 14.6 \mathrm{~kg} / \mathrm{m}^{2}$ (25 c) and genetic examination for celiac disease resulted in positive HLA-DQ2 (positive: DQ1 ${ }^{*} 05, \mathrm{DQB} 1^{\star} 02, \mathrm{DQB} !^{\star} 02 /^{*} 0302$, HLA-DQ2) and negative HLA-DQ8, which confirmed the genetic basis of celiac disease in the boy. At present, the child remains on a restrictive gluten-free diet and normal physical and mental development is observed (good marks at school, cheerful, sociable).

Child 3: the youngest of siblings - a 19-month-old girl with CIVPIII, born on time, spontaneous labour, body weight 3000 g, Apgar 10 scores, still breastfed, additional products were introduced in accordance with the feeding guidelines, including gluten from the fifth month of life. After gluten introduction her stools changed consistency into more compact. When an attempt was made to introduce cow milk into the diet, traits of atopic diathesis appeared on the face. The child remains under permanent cardiac care due to congenital heart disease (ASD and Fo).

At the age of 6 months, her body weight was $7000 \mathrm{~g}$, height $67 \mathrm{~cm} \mathrm{(50} \mathrm{c)} \mathrm{and} \mathrm{BMI} 15.6 \mathrm{~kg} / \mathrm{m}^{2}(25-50 \mathrm{c})$, and at the age of 17 months these parameters were, respectively: $9900 \mathrm{~g}(10-25 \mathrm{c}), 84 \mathrm{~cm}(75-90 \mathrm{c})$ and BMI $14 \mathrm{~kg} / \mathrm{m}^{2}$ $(15-25 \mathrm{c})$. A serological test was performed at that time for celiac disease but gave a negative result (tTGA IgA $<0.6 \mathrm{U} / \mathrm{ml}$, EMA IgA and IgG - not detected, anti-DPG IgA and IgG - not detected), but it transpired that within the previous months the mother had not fed the girl with gluten. Due to the positive family history of celiac disease 
the girl was qualified for genetic predisposition test for this disease. The result of genetic test was HLA-DQ2/DQ8 negative. The mother was informed about the result and gradual introduction of gluten into the diet was planned.

\section{Parents}

Father, 46 years old, body weight $68 \mathrm{~kg}$, height $176 \mathrm{~cm}$ and BMI $22 \mathrm{~kg} / \mathrm{m}^{2}$. In the early years of his life he suffered from recurrent respiratory infections, diarrhoea, abdominal pain and aphthae on oral cavity mucosa, then at the age of 16 he was treated due to tuberculosis (similar pathological symptoms and tuberculosis in the medical history of his father). Due to abdominal pain, loose stools and weakness, at the age of 40 years he decided to exclude gluten from his diet (both his sons already followed a gluten-free diet). After about 2 weeks of the diet he noticed improvement in his general feeling and regression of abdominal pain and previously observed bad breath. The genotype examination for HLADQ2/DQ8 was negative, which rather allows exclusion of genetic susceptibility to celiac disease.

The patient on his own, without any arrangements, had serological tests performed: IgE specific for wheat, rye and gluten in class 0 , total IgA and IgE concentration within normal limits and tTGA IgA $<0.6 \mathrm{U} / \mathrm{ml}$. Serological testing performed in the course of a diet has no diagnostic significance and thus does not allow confirmation or exclusion of food allergy to gluten. The patient was informed about the need of provocation with small doses of gluten in the diet.

Mother, 46 years old, body weight $70 \mathrm{~kg}$, height $172 \mathrm{~cm}, \mathrm{BMI} 23.7 \mathrm{~kg} / \mathrm{m}^{2}$. Her history included, up to 7 years of age, recurrent respiratory infections and suppurative otitis media, abdominal pain (due to which, she was hospitalized at the age of 11 years, aetiology of complaints not established) and within the last 10 years periodical episodes of abdominal pain, in the last months radiating down the left hip. A positive result of genotype determination for celiac disease was obtained for HLA-DQ2 (positive: DQA1*05, DQB1*02, DQB1 ${ }^{\star} 02 /{ }^{*} 0302, \mathrm{HLA}-\mathrm{DQ} 2$ - the same as in her younger son), negative HLA-DQ8, total concentration of immunoglobulin $A$ and $E$ - result in the normal range and tTGA IgA $7.84 \mathrm{U} / \mathrm{ml}(\mathrm{N}:<8)$ (Table II). The mother was recommended to follow a temporary semi-elementary diet; after 3 weeks of diet implementation the patient noticed a decrease in the severity of abdominal pain and an improvement in general feeling. The introduction of a gluten-free diet on an everyday basis remains under consideration. She has periodically followed this diet due to the other members of her family remaining on this diet. She decided to perform further examinations, including endoscopic examination, after gluten provocation.

\section{Discussion}

Recognition of celiac disease is based on serological and genetic diagnostics as well as on small-intestinal biopsy (with histological evaluation of the segments). The serological diagnostics of celiac disease include the determination of tissue anti-transglutaminase antibodies (tTGA), smooth muscles antiendomysial antibodies (EMA) in class IgA, and in the case of IgA deficit - in class IgG (determination of total IgA is necessary when the results of tTGA and EMA are negative). Since 2007, anti-synthetic deamidated gliadin peptide (DGP) antibodies have been determined. Antibodies against new autoantigens have also been described, e.g. anti-neuro-

Table II. The results of laboratory tests of individual family members

\begin{tabular}{|c|c|c|c|c|c|c|}
\hline Variable & $\begin{array}{l}\text { tTGA IgA (N: } \\
<8.0 \mathrm{U} / \mathrm{ml})\end{array}$ & $\begin{array}{c}\text { EMA } \\
\text { IgA/IgG } \\
\text { (border titer } 1: 5 \text { ) }\end{array}$ & $\begin{array}{c}\text { AGA IgA/lgG } \\
(\mathrm{N}:<11.0 \mathrm{U} / \mathrm{ml})\end{array}$ & $\begin{array}{l}\text { IgE specific } \\
\text { gluten }\end{array}$ & $\begin{array}{c}\text { IgE specific } \\
\beta \text {-lactoglobulin }\end{array}$ & $\begin{array}{l}\text { HLA-DQ2/DQ8 } \\
\text { genetic } \\
\text { examination }\end{array}$ \\
\hline Elder son & 0.2 & & $\begin{array}{l}2.0 \\
3.90\end{array}$ & Class 2 & Class 2 & Negative \\
\hline Younger son & 69.7 & & $\begin{array}{l}1.4 \\
5.0\end{array}$ & Class 2 & Class 2 & $\begin{array}{l}\text { DQ2 positive } \\
\text { DQ8 negative }\end{array}$ \\
\hline Daughter on GFD & $<0.6$ & Not detected & $\begin{array}{l}\text { Anti-DPG IgA } \\
\text { and IgG } \\
\text { Not detected }\end{array}$ & - & - & Negative \\
\hline Mother & 7.84 & Not detected & Not detected & - & - & $\begin{array}{l}\text { DQ2 positive } \\
\text { DQ8 negative }\end{array}$ \\
\hline Father on GFD & $<0.6$ & - & - & Class 0 & - & Negative \\
\hline
\end{tabular}


nal transglutaminase antibodies (a marker of neurological forms of celiac disease) $[5,6]$.

According to the latest ESPGHAN guidelines from 2012, it is possible to resign from a small-bowel biopsy in patients with clinical symptoms characteristic for celiac disease, in whom additionally the presence of anti-tissue transglutaminase antibodies ( $>10$ times the upper limit of normal) has been confirmed along with the presence of EMA and a positive result of genetic examination [4]. It has been proven that HLA-DQ2 and HLA-DQ8 genes located on chromosome 6p21 are associated with celiac disease in almost $100 \%$ of cases. About $90-95 \%$ of patients with CD express HLA-DQ2, and the remaining patients (5-10\%) are usually HLADQ8 positive. Only about $1 \%$ of CD patients do not express HLA-DQ2/DQ8 gene. In these patients, mutations of genes encoding molecules and mediators of immune reactions (CTLA-4), mutations of genes encoding proteins of intraepithelial junctions, and others, might be responsible for the development of the disease. It should be remembered that $30 \%$ of the healthy population also possess HLA-DQ2 or HLA-DQ8 genes. HLADQ2 or HLA-DQ8 carry a high negative predictive value for $C D$ and serve mainly to exclude diagnosis of celiac disease (which was used in the case of the family investigated by us) [5, 7-9].

In our study we have presented a family in whom, primarily based on clinical symptoms, hypersensitivity to gluten was diagnosed in the elder son. When the younger son started complaining of abdominal pain and abnormal bowel movement, and when a milk-free diet did not result in improvement, it was decided (late, at the age of 3 years) to put him on a gluten-free diet, which, combined with a milk-free diet, gave some clinical improvement.

The boys never had endoscopic and histological evaluation of mucosa, which is obligatory according to diagnostic standards. The parents, for fear of the potentially harmful effect of anaesthesia on their children (endoscopy with intestinal biopsy is performed in small children under general anaesthesia), did not give their consent for the procedure.

The abdominal pain, abnormal bowel movements and general discomfort observed in the boys' father encouraged him to eliminate gluten from his diet, and he felt subjective improvement. When a baby-girl was born, the mother introduced gluten into her diet for a short time, but the change in stools and positive family history for CD made her withdraw gluten from the diet.

The presented description of the family points to the importance of genotype testing in individual members of a family in the diagnostic process of ce- liac disease and in establishing further therapeutic management (including the diet). The positive (identical) result of HLA-DQ2 test was obtained in the mother and the younger son (positive: $\mathrm{DQA} 1^{*} 05, \mathrm{DQB} 1^{\star} 02$, $\mathrm{DQB} 1{ }^{\star} 02{ }^{*} 0302$, HLA-DQ2). Therefore, a life-long gluten-free diet was recommended to the child.

A negative result of HLA-DQ2/DQ8 allele test allowed cessation of the gluten-free diet in the elder son (the diet was maintained without whole milk), daughter and father. Although both the elder son and the father presented with symptoms listed among those characteristic of celiac disease, they were not associated with this disease. In the father, professional and family stress and perhaps the reaction of the gastrointestinal tract (not severe) to complex four-drug therapy of tuberculosis and/or hypersensitivity to gluten, were most probably responsible for the above-mentioned gastrointestinal symptoms. In the elder son, abdominal pain, abnormal bowel movements and atopic skin changes were associated with the consumption of whole cow milk and IgE-dependent hypersensitivity to gluten.

We found an abnormal reaction to gluten in this family in the form of permanent intolerance diagnosed as celiac disease or as hypersensitivity to gluten (IgE-dependent).

The described family is an example of the need for qualification for celiac disease testing of first-degree relatives of a patient with this disease. Studies have confirmed that celiac disease is more frequently observed in such individuals than in the whole population, and it is more often diagnosed in the patient's siblings $(2.7-12.5 \%)$ than in parents $(0-8.8 \%)$ or offspring $(0-$ $11.8 \%)$ [10].

The high predictive value of both positive and negative results of genetic tests (HLA-DQ2/DQ8) and their greater availability as well as non-invasive character and constantly falling price are arguments for performing genotyping in risk-group individuals such as first-degree relatives of celiac patients and patients with type 1 diabetes, autoimmune thyroiditis, autoimmune hepatitis, Down's syndrome and Turner syndrome [11].

\section{References}

1. Gujral N, Frejman HJ, Thomson A. Celiac disease: prevalence, diagnosis, pathogenesis and treatment. World J Gastroenterol 2012; 18: 6036-59.

2. Karczewska K. Coeliac disease, contemporary clinical picture and diagnostics. Pediatr Współcz Gastroenterol Hepatol Żyw Dz 2006; 8: 220-1.

3. Kaniewska M, Rydzewska G. Celiac disease in adults - pathogenesis, clinical manifestations, coexistens with inflammatory bowel disease and other diseases with immunological background [Polish]. Prz Gastroenterol 2009; 4: 173-7. 
4. Husby S, Koletzko S, Korponay-Szabo IR, et al. ESPGHAN guidelines for the diagnosis of coeliac disease in children and adolescents. An evidence - based approach. J Pediatr Gastroenterol Nutr 2012; 54: 136-60.

5. Cukrowska B. Novel diagnostic possibilities of celiac disease. Pediatr Współcz Gastroenterol Hepatol Żyw Dz 2009; 11: 93-7.

6. Prause C, Ritter M, Probst C, et al. Antibodies against deaminated gliadin as new and accurate biomarkers of childhood celiac disease. J Pedatr Gastreonterol Nutr 2009; 49: 52-8.

7. Iwańczak F, Iwańczak B. New guidelines for diagnosis and treatment of coeliac disease in children and adolescents [Polish]. Prz Gastroenterol 2012; 7: 185-91.

8. Megiorni F, Mora B, Bonamico $M$, et al. HLA-DQ and risk gradient for celiac disease. Hum Immunol 2009; 70: 55-9.

9. Rybak A, Szperl M, Burda-Muszyńska B, et al. Review on the genetic background of the celiac disease. Ann Diagn Paediatr Pathol 2008; 12: 5-8.

10. Bonamico M, Mariani P, Mazzilli MC, et al. Frequency and clinical pattern of coeliac disease among siblings of coeliac children. J Pediatr Gastroenterol Nutr 1996; 23: 159-63.

11. Szaflarska-Popławska A. Liver injury in coeliac disease - own study and review of literature. Prz Gastroenterol 2011; 6: 259-66.

Received: 21.12 .2012

Accepted: 8.02.2013 